Article

\title{
Food Democracy as 'Radical' Food Sovereignty: Agrarian Democracy and Counter-Hegemonic Resistance to the Neo-Imperial Food Regime
}

\author{
Mark Tilzey \\ Centre for Agroecology, Water and Resilience, Coventry University, Coventry, CV8 3LG, UK; \\ E-Mail: mark.tilzey@coventry.ac.uk
}

Submitted: 15 March 2019 | Accepted: 24 July 2019 | Published: 28 October 2019

\begin{abstract}
This article argues that a thoroughgoing and meaningful food democracy should entail something closely akin to 'radical' food sovereignty, a political programme which confronts the key social relational bases of capitalism. The latter comprise, in essence, 'primitive accumulation,' the alienability or commodification of land and other fundamental use values, and market dependence. A thoroughgoing food democracy of this kind thus challenges the structural separation of the 'economic' and 'political' spheres within capitalism and the modern state (the state-capital nexus), a separation which enables purely political rights and obligations ('political' freedom or formal democracy) whilst simultaneously leaving unconstrained the economic powers of capital and their operation through market dependence ('economic' unfreedom or the lack of substantive democracy). We argue that much 'food democracy' discourse remains confined to this level of 'political' freedom and that, if food sovereignty is to be realized, this movement needs to address 'economic' unfreedom, in other words, to subvert capitalist social-property relations. We argue further that the political economy of food constitutes but a subset of these wider social relations, such that substantive food democracy is seen here to entail, like 'radical' food sovereignty, an abrogation of the three pillars upholding capitalism (primitive accumulation, absolute property rights, market dependence) as an intrinsic part of a wider and more integrated movement towards livelihood sovereignty. We argue here that the abrogation of these conditions upholding the state-capital nexus constitutes an essential part of the transformation of capitalist social-property relations towards common 'ownership' - or, better, stewardship — of the means of livelihood, of which substantive food democracy is a key component.
\end{abstract}

\section{Keywords}

agrarian democracy; counter-hegemony; food democracy; food sovereignty

Issue

This article is part of the issue "New Perspectives on Food Democracy" edited by Basil Bornemann (University of Basel, Switzerland) and Sabine Weiland (Université Catholique de Lille, France).

(C) 2019 by the author; licensee Cogitatio (Lisbon, Portugal). This article is licensed under a Creative Commons Attribution 4.0 International License (CC BY).

\section{Introduction}

This article contends that if food democracy is to realize its full potential, it should entail something closely akin to 'radical' food sovereignty. This represents a political programme which, actually or by implication, challenges the essential social relational foundations of capitalism. 'Radical' food sovereignty is here differentiated from 'progressive' food sovereignty, the latter having much in common with 'formal' food democracy and the current discourse of 'food as a commons' in its deficient understanding of, most saliently, capitalism, the state, and class (see for discussion of food democracy and 'food as a commons': Vivero-Pol, Ferrando, de Schutter, \& Mattei, 2019; see for discussion of 'radical' and 'progressive' food sovereignty: Holt-Gimenez \& Shattuck, 2011; Tilzey, 2017, 2018). The key social relational foundations of capitalism comprise 'primitive accumulation'-which entails the commodification of labour power attendant on the expropriation of producers from their means of production-, the alienability or commodification of land and other fundamental use values-the conferral of ab- 
solute property rights over land and other fundamental use values necessary for human existence-, and market dependence-dependence on the capitalist market in order to secure the means of livelihood. Our model of food democracy thus throws into question the structural separation of the 'economic' and 'political' spheres within capitalism and the modern state (the state-capital nexus). This duality confers purely political rights and obligations ('political' freedom or formal democracy) whilst simultaneously exempting from constraint the economic powers of capital and their operation through market dependence ('economic' unfreedom or the lack of substantive democracy; see Tilzey, 2017, 2018, for further details).

We contend that prevalent 'food democracy' (and closely related 'food as a commons') discourse remains limited to this level of 'political' freedom (see for overviews Hassanein, 2008; Vivero-Pol et al., 2019). We suggest that food democracy in this form needs, therefore, to widen its remit to address 'economic' unfreedom, in other words to subvert capitalist social-property relations, if food sovereignty is ever to become reality. We argue further that the political economy of food comprises but a part of these wider social relations. In this way, substantive food democracy is considered here to require, like 'radical' food sovereignty, an abrogation of the three supporting pillars capitalism (primitive accumulation, absolute property rights, market dependence), an integral element in a broader and more coherent movement towards livelihood sovereignty (Tilzey, 2018). We contend that the demolition of these pillars upholding the state-capital nexus represents a key element of the transformation of capitalist social-property relations towards common 'ownership' - or, better, stewardship-of the means of livelihood, of which substantive food democracy is a key component. Here we should note that 'stewardship' implies a relation of guardianship towards the means of livelihood, abrogating thereby notions of absolute property rights, or complete dominion, over nature and other members of society.

In exploring the discourse of food democracy, this article deploys a theoretical perspective which integrates political Marxism (Brenner, 1985; Wood, 1995), neo-Gramscian international political economy (Bieler \& Morton, 2004; Cox, 1993), regulation theory (Boyer \& Saillard, 2002; Jessop \& Sum, 2013), and Poulantzian state theory (Poulantzas, 1978). The article also has affinities with the important work on imperialism and sub-imperialism of Ruy Mauro Marini (see Marini, 1972, 1973). This approach stands in contrast to 'populism' in agrarian political theory, represented by McMichael (2013) and van der Ploeg (2008), for example, the latter having strong affinities with 'formal' food democracy. This 'populism,' like 'formal' food democracy, is characterized by an elision of class (particularly in respect of class differentiation amongst the 'peasantry'), a radical under-theorization of the state, and assumptions regarding the full trans-nationalization and unity of capital. This article does concur with agrarian 'populism,' however, in its concern for the ecological dimension and its advocacy of agroecology (Altieri \& Toledo, 2011) and food sovereignty-the latter, though, on its 'radical' definition (see Tilzey, 2018, for full elaboration of an ecological perspective as political ecology). It stands also in contrast to 'orthodox' Marxism, represented for example by Bernstein (2010) and Jansen (2015), characterized by its class reductionism, its instrumentalist view of the state, its reification of developmentalism, and its failure to comprehend the profound importance of the ecological dimension.

Deploying this approach, we suggest that food democracy remains inadequate to its task if it fails to address the social-property relations underpinning capitalist food regimes; and that its singular focus on 'democracy' (the reified sphere of 'politics') rather than addressing political economy (the dialectical relation between the 'political' and the 'economic') is symptomatic of its differential locus in the global North, and its association with 'progressive', rather than 'radical,' food sovereignty (see Tilzey, 2017). The former assumes that food democracy is somehow 'beyond class' other than in terms of the simplistic binary between the 'empire' of the 'corporate' food regime and the 'multitude' of civil society. We emphasize that the term 'class' is deployed in this article, by contrast, in a non-reductive sense, whereby power relations and exploitation may be expressed and take place through class, ethnic, racial, gender, religious, etc. categories. It is also to recognize that 'objective' class position may not translate into 'subjective' class positionality, and that the latter can only be understood through the ways that exploitation and discrimination are actually experienced and understood by actors, as expressed in terms of 'cultural politics.' Such a non-reductive understanding of class follows in the political and cultural traditions of Marxian thinking exemplified by, for example, Gramsci (1971) and Thompson (1991). Accordingly, we maintain that 'class struggle' remains fundamental to the dynamics of the state-capital nexus and its food regimes, and to the possibility of its subversion, not by the 'multitude' as a generality, but rather by particular classes which, located overwhelmingly in the global South, have undergone least absorption into the economic and political structures of liberal democracy.

If not the 'multitude' of civil society, then, which social interests and forces are likely to advocate and carry through such a programme of 'radical' food sovereignty (which we might otherwise term substantive food democracy, agrarian democracy, or, more integrally, livelihood sovereignty)? We argue that such interests and forces comprise in the main the 'precariat' of the global South-the middle/lower peasantry, informal sector workers, and indigenous groups. Unlike the majority in the global North (and selectively in the BRICS sub-imperium), whose consumer lifestyles are sustained actually, or integrated normatively, into the capitalist 'imperial mode of living' (a neo-imperial relation with the global South; Brand \& Wissen, 2018) and into the 
norms of liberal democracy, this Southern precariat increasingly sees little hope of salvation in capitalist 'development' or in the machinations of 'representative' democracy (the term 'neo-imperial' represents the application of neoliberal policies in the global South under the auspices of imperial powers and collaborating Southern elites. The terms 'neo-imperial' and 'neoliberal' can in this article be treated, therefore, as virtual synonyms). It seeks, therefore, an alternative future premised on land redistribution, agroecological production to meet fundamental social needs, and participative democracy (see Intriago, Gortaire Amézcua, Bravo, \& O'Connell, 2017; Tilzey, 2019a). Such a view is captured in the Andean concept of buen vivir (Giunta, 2014; Intriago et al., 2017). This approach combines the need to address both the discursive and the material (social property relations; the 'political' and the 'economic') bases of oppression and marginalization in order to secure livelihood sovereignty. The approach in this article, then, comprises both analytics of the state-capital nexus and its food regimes through an ontology of political ecology (Tilzey, 2018), and explores reflexive politics as a 'political (agro)ecology of praxis.' The latter is the translation of this political ecological ontology, through agroecology, into a programme political action. This analytical frame and exploration of praxis as counter-hegemonic resistance are examined in relation to Latin America, and Bolivia and Ecuador particularly. In these latter states, the peasantry and indigenous groups were instrumental in overturning neoliberalism in the 1990s and 2000s, only to have their programme of 'radical' food sovereignty subsequently co-opted and subverted by reformist capitalism and liberal democracy. The ongoing dynamics of resistance, and the prospects for substantive food democracy as 'radical' food sovereignty in these two states, are explored in the latter part of the article.

\section{The Shortcomings of 'Formal' Food Democracy}

The imaginary of 'formal' food democracy differs from the discourse on the Right to Food, from which it in part arises, in its specific identification of the putative causal basis of the lack of this 'right.' This causal basis, it asserts, arises from the fact that capitalist economies, or, more specifically, the 'corporate' food regime (McMichael, 2013), have, since the 1980s, increasingly constrained the democratic capacity of liberal states, and popular demands cannot be reconciled with what is assumed by its proponents to be a state-market duopoly (see Hassanein, 2008; Vivero-Pol et al., 2019; see below for critique of this binary view of the 'state' and 'market'). 'Formal' food democracy 'scrutinizes the constitutional surface of the liberal state' (Holt-Gimenez \& van Lammeren, 2019, p. 320) under which 'corporate actors' are assumed to be the primary architects of what elsewhere has been termed the 'neoliberal' food regime (Tilzey, 2019b). In order to address this assumed co-optation of the 'state' by 'corporate actors,' 'formal' food democracy envisions a broader 'communicative realm' not confined to liberal constitutionalism, but focused rather on the way 'discursive sources of order' can influence governance (Dryzek, 2000). 'Food democracy is about citizens....being afforded an equal opportunity to participate in decisions that affect them' (Hassanein, 2008, p. 287) where these relate to food and food policy. 'Formal' food democracy thus proposes 'discursive democracy' in which 'citizens' or 'civil actors' (part of an undifferentiated 'multitude') democratize governance by contesting established conventions and influencing decision-making bodies through deliberative, rather than electoral, means (Holt-Gimenez \& van Lammeren, 2019).

The challenge for proponents of 'formal' food democracy, then, is somehow to discursively construct a different food regime, proposed to comprise elements of socialization, de-commodification, localization, 'commoning', etc. (Vivero-Pol et al., 2019), when in reality this requires material as well as discursive transformation away from capitalist social-property relations. Moreover, this is supposed to occur within a political structure of liberal democracy that is actually the integral counterpart of capitalist relations of production, founded on individual rights and private property (the state-capital nexus; Tilzey, 2019b). For 'formal' food democracy, it is supposed that the discursive revalorization of food, involving inter alia the ideological rejection of food as a 'pure commodity' (neglecting, thereby, the material and class predicates of food as commodity), enables a diversity of actors to come together so that, once enlightened with the rationale of 'food democracy,' they assume agency as 'food citizens' (Holt-Gimenez \& van Lammeren, 2019; Vivero-Pol, 2017). This assumes that agents can engage in 'pure agency' abstracted from their own structured positions and without transforming the social-property relations which underpin the state-capital nexus. A more nuanced approach would be to understand that agents act within and upon pre-given structural constraints and opportunities rather than being somehow autonomous from them. This view is captured in the notion of 'structured agency' (Potter \& Tilzey, 2005) and in the 'strategic relational approach' (Jessop, 2005). In its voluntarism, 'formal' food democracy thus dichotomizes 'positionality,' an agent's 'subjective' view on an issue, from 'class position,' an agent's 'objective' capacity or ability to transform structures to conform with this view, the latter in fact no longer recognized as an issue in the post-structural problematic of the 'new social movements.' This is analogous to the difference between a formal 'right to benefit' and a substantive 'ability to benefit' (Ribot \& Peluso, 2003).

The shift from liberal constitutionalism to the reflexive agency of civil actors embodied in 'formal' food democracy is illustrated by the proposal for 'tricentric governance' whereby 'self-regulated, civic collective actions for food' acquire increased purchase over 'state' and 'market' (Vivero-Pol, 2017, 2019). Tricentric governance putatively rebalances the relative influence between 'state,' 'economy' and civil actions through the re- 
appropriation of public space from the first two in favour of the third, with civil actors assuming an agency of their own. In this way, a 'mounting force of citizens' actions to reclaim food' pressurizes the 'state' to shift from facilitator of capitalist 'accumulation through enclosure' to regulator of the same, and provider of enabling frameworks for food citizens. Thus, during this envisioned transition towards a new food regime, the 'state' is enjoined to provide incentives and enabling frameworks, such as basic food entitlement and food security floors, support for alternative initiatives for food production and food sharing at local scales, all effectively scaling back the jurisdiction of both 'state' and 'market' (Holt-Gimenez \& van Lammeren, 2019; Vivero-Pol, 2019). According to this 'tricentric governance' model, self-organized groups under self-negotiated rule develop 'food democracies,' operating through 'nodes' of connected but autonomous food centres, attaining free association between producers and consumers (Caffentzis, 2010). At this point, the role of the 'state' as regulator and provider of enabling frameworks can diminish and both 'states' and 'markets' are demoted to simply one of many ways of allocating resources.

The concept of tricentric governance within 'formal' food democracy thus deploys an imaginary in which the valuation of food as a common good unites otherwise disparate actors within and across nation-states and the global North-South divide (the 'multitude'), elevating food, in effect, above the capitalist mode of production in which it is currently embedded (Vivero-Pol et al., 2019). This narrative thus proposes that, were food considered to be subject to this deeper discursive democracy, the global food system, together with capitalism, would change (Vivero-Pol, 2017). In other words, the extraordinary agency for change assumed by food democracy advocates arises from the 'unforced force of the better argument' alone (Habermas, 1996, p. 306). Thus, it is asserted that the ideational power of discursive democracy alone is a sufficient propellant to reconfigure the neoliberal food regime's governance structure.

Salient amongst the shortcomings of 'formal' food democracy as described above is the assumption that discursive, deliberative democracy alone will engender a transformation towards more socially and ecologically sustainable forms of production, with the principal political agent here being the global Northern 'eater' or food citizen (Hassanein, 2008; Holt-Gimenez \& van Lammeren, 2019). Symptomatically, it is democratic force of argument alone, dissociated from questions of the ownership of, and access to, the means of production or of the necessary redistribution of these means, which is identified as the means to secure transformational change. This assertion is in itself an inherently liberal and 'postmodern' conception, drawing on the favoured 'postMarxist' thinking of Polanyi (1957; see Tilzey, 2017, for extended critique of Polanyi) and Hardt and Negri (2000). As we shall suggest below, it is no accident that this particular imaginary of change should be associated with the global North, where affluence, increasingly dependent on exploitation of the South, permits the educational, employment, welfare, and wider citizenship benefits which permit positionality to be (relatively) divorced from class position and from the wider material predicates that enable such 'reflexive citizenship.' In other words, affluence may afford the insulation from the 'dull compulsion of the economic' which enables agents to (relatively) divorce their views as 'citizens' (positionality) from their immediate interests in the capitalist mode of production from which that very affluence derives (class position). By dissociating discursive democratic change from the need to address social-property relations upheld by the state-capital nexus, 'formal' food democracy effectively leaves much of capital's power intact (HoltGimenez \& van Lammeren, 2019). By the same token, this elevation of citizen positionality at the expense of class position as in the notion of the 'multitude,' obscures difference and embedded asymmetries, serving only to reproduce them. This is particularly true of the profound asymmetries between North and South, which asserted commonalities of 'citizen interest' serve to disguise and therefore perpetuate.

In short, 'formal' food democracy remains ensnared in a symptomatically Northern preoccupation with 'right to benefit,' thereby ignoring the material predicates of the 'ability to benefit' (Ribot \& Peluso, 2003). In other words, abilities to benefit from institutions and resources are shaped by class and wider social-property relations instantiated in the state-capital nexus. Recognition of this fact requires a shift from 'formal' to 'substantive' food democracy. Such 'substantive democracy' has certain similarities with Bornemann and Weiland's discussion of different and complementary forms of empowerment which are 'concerned with the development of different forms of political power that, in turn, are related to different democratic principles, such as participation ("power to"), deliberation ("power with") and representation ("power over"). Thus, empowerment is not as such democratic; rather, empowerment is a process of power generation that creates the conditions for democracy.' (Bornemann \& Weiland, 2019, p. 108). 'Formal' food democracy, by contrast, conflates discourse, democracy, and equality, obstructing their strategic relational assessment. Subverting the neoliberal food regime requires the de-commodification and dismantling of the key structural (not merely discursive) underpinnings of capitalist social-property relations (see below). In other words, constructing an anti-capitalist food regime, or 'substantive' food democracy, will be predicated on 'class struggle' (Federici \& Caffentzis, 2014; Tilzey, 2019b).

The deficiencies of 'formal' (or 'progressive,' rather than 'radical') food democracy may thus be summarized as follows:

First, it reifies the 'political' and focuses on discursive elements, while neglecting the social-property relations underlying capitalism-i.e., it focuses on the 'demo- 
cratic deficit' to the neglect of 'relations of production and exploitation.'

Second, it has no, or an inadequate, theory of the state, this being seen in essentialist terms usually as an institution opposed to the 'market,' reflecting simplistically the 'will of the people,' rather than as a 'social relation reflecting the balance of class interests in society.'

Third, and relatedly, it has no, or a deficient, understanding of 'class' and 'class struggle,' it being assumed that somehow 'civil society' and 'democracy' have moved 'beyond class' in the manner of the 'new social movements.'

Fourth, again relatedly, it holds a binary view of contestation between the 'multitude' of civil society versus the 'corporate' food regime, in which the 'state' is called upon to 'regulate' the latter and 'protect' the former in Polanyian fashion. This reflects an undifferentiated view of what is actually class-bound society, an inadequate theory of the state (see above), and a simplistic view of capital as being undifferentiated and wholly transnational in orientation.

Fifth, it demonstrates an almost complete lack of awareness of the differentiation of the capitalist world system into an imperium (the global North) and a periphery (the global South), whereby the former, particularly under the 'new imperialism' of neoliberalism, is able to sustain consumer, welfare, and liberal democratic benefits at the expense of the latter, whence the bulk of primary commodities and surplus value is now extracted as 'cheaps.' By contrast, it is commonly assumed by 'progressives' and advocates of 'formal' food democracy, that the 'multitude' in general, North and South, is equally subject to the predations of the 'corporate' food regime and requires a similar response by the 'state' or by 'supra-state' institutions.

Sixth, it elevates initiatives in 'food democracy' to the status of serious challenges to neoliberalism/capitalism, when more frequently these merely subsist in the interstices of capitalism and may, indeed, conform to the process of neoliberal 'de-statization,' whereby the state-capital nexus encourages the devolution and divestment of former state responsibilities to communityled schemes.

\section{Defining a Theoretical Basis for 'Radical' Food Democracy (as Food Sovereignty) and Understanding the Causal Basis of 'Formal' Food Democracy}

In order to define both the 'political' and 'economic' bases for 'radical' food democracy, we need to understand the nature of the entities which require subversion to achieve this end, together with the nature of the (class) agents/agency that might be able to bring this about. This requires us to develop a much more sophisticated understanding of capitalism, state, and class than is deployed by proponents of 'formal' food democracy. In terms of capitalism and the modern state, we need to understand the twin aspects of this relation that enable us to make sense of both entities in their dialectical co-constitution: The 'separation in unity' of the institutional spheres of the 'economy' and 'polity,' and the complementary accumulation and legitimation functions of the state in relation to capital as defined, helpfully, by regulation theory (Boyer \& Saillard, 2002). 'Progressives' and 'formal' food democracy advocates deploy a dichotomous, rather than dialectical, understanding of the state-capital relation, with both entities reified and de-historicised. We suggest that an understanding of the state-capital relation needs to go far deeper than this, however. Following Poulantzas (1978), it is more helpful to see the state, given the lack of 'extraeconomic' influence that individual capitals can exert, as providing the essential institutional space for various fractions of the capitalist class, in addition possibly to other classes, to come together to form longerterm strategies and alliances whilst, simultaneously, the state disorganises non-capitalist classes through various means of co-optation and division. The state, also for reasons of legitimation, must, additionally, be 'relatively autonomous' from the interests and demands of particular fractions of capital, and even from capital 'in general.' So, as Poulantzas (1978) suggests, the state represents the condensation of the balance of class forces in society. For advocates of 'formal' food democracy, by contrast, capital is a unitary entity, bereft of specific class and class fractional content. This is counter-posed to a 'state,' a content-less abstraction which apparently represents, without mediation, the position of a generalised counter-movement. This aligns with a Polanyian (Polanyi, 1957), indeed neoclassical, conception of the state and capital as essentialised and opposed entities.

We suggest, therefore, that the modern state is better conceptualised as itself a social relation. That is, an arena or container (the state-capital nexus; Taylor, 1994; van Apeldoorn, de Graaff, \& Overbeek, 2012), within which class contestation and compromise is played out, principally to secure the material and ideological reproduction of the hegemonic fractions of capital, even where these may be transnational in orientation. Thus, within capitalism, the institutionally separated spheres of the 'political' and the 'economic' are dialectically cognate and implied, with their very 'separation in unity' a consequence of the commodification of labour power and the establishment of absolute property rights in the means of production. At the same time, the modern state acquires a strategic 'political' role which the individual capitalist cannot fulfil. The state was instrumental in effecting the process of 'primitive accumulation' which created a proletariat 'free' to sell its labour power to the capitalist (Perelman, 2000), in other words, of founding the material and class relations (socialproperty relations) on which capitalism is founded. Once capitalism was installed, the state deployed its power further to maintain and guarantee absolute property rights by the capitalist class, and to institute and support regimes of work discipline required by this new mode 
(Wolf, 1982, p. 100). The modern state also assumed the essential role of arbitrating and managing contestation between fractions of capital (inter-capitalist competition), and between capitalists and its labour force, and of representing the interests of capital in the international arena.

This also points to the vital importance of class interests in the dynamics of food regimes, one which confounds the 'formal' food democracy assumption regarding a simple binary of 'civil society,' acting 'beyond' class, in opposition to 'corporate' interests. The reality is that the interests being deployed in food system dynamics are much more differentiated and class-bound than is implied in this binary assumption. In fact, the prime mover in the formation and reproduction of food regimes is the social-property (class) relations in the hegemonic state (in the world system) and the international articulation of these relations with receptive and complementary class interests in other states (Tilzey, 2019b).

This understanding of the capital-state-class relation makes it clear that liberal democracy, or even deeper forms of democracy where confined to the discursive or 'political' level, mask more profound forms of unfreedom based in capitalist social-property relations. This 'citizenship illusion' arises from the reified structure of capitalist social relations itself. It comprises an 'objectified illusion' which reveals and conceals simultaneously: It 'reveals' certain limited rights and freedoms in the 'political' sphere whilst concealing the class inequalities of the 'economic' sphere (Wood, 2005). As a reified social form, liberal democracy both constrains certain types of social action or existence, such as the ability to freely access the means of production or subsistence, whilst enabling others, such as being 'free' to compete in the capitalist market. The structural separation of the 'economic' and 'political' spheres within the modern state was thus intended to constrain actions which might impinge on the economic powers of capital (such as free access to the means of subsistence), whilst enabling purely political rights and obligations (Mooers, 2014; Wood, 1991). We suggest that 'formal' food democracy remains in important respects ensnared in this 'citizenship illusion,' the latter designed to conceal the deeper contradiction between politico-legal equality, on the one hand, and class inequality and exploitation, on the other. As we shall argue below, even the conferral of such constrained, liberal citizenship rights has been contingent on imperialism and the territorial form of the state, defining those substantively included in citizenship rights (the majority in the global North) and those substantively excluded (the majority in the global South). This is why Marx (1981) insisted that political emancipation embodied in abstract citizenship remains only a partial victory, and one rendered more partial still because of its reliance on the 'spatio-temporal' fix that is imperialism. This is why, we argue, 'formal' food democracy remains inadequate to the task of fulfilling the mission of 'radical' food sovereignty-radical egalitarianism (Patel,
2011) - , since this requires the abrogation of the key social-property relations underpinning the capital-state nexus (see below).

Liberal democracy, deployed by the state-capital nexus, has been a powerful means of co-opting noncapitalist classes and deflecting attention away from the exploitative and class-based nature of capitalism. This ability to co-opt and deflect resistance has been differentially located in the global North, however, based in hegemony (as domination through consensus) founded on material rewards (consumerism), nation-building, and the bestowal of politico-legal rights that follow from citizenship. This liberal democratic consensus attained its apogee during the Keynesian era, but has been under increasing strain during the course of neoliberalism. In the face of increased neoliberal class exploitation, attempts to sustain this class compact in the global North have been undertaken increasingly by means of imperial relations, both 'informal' (economic) and 'formal' (politico-military) with the global South. Resurgent neoliberal primitive accumulation, with the state acting as an organ of the expropriators and agro-exporting fractions of capital, has served to undermine the legitimacy functions of the state-capital nexus throughout much of the global South. The outcome of this new imperial relationship between the North and South is that citizens of the former are accorded economic and political privileges denied to those in the capitalist periphery. These privileges form the unacknowledged basis for the imaginary of 'formal' food democracy, tied implicitly to this 'imperial mode of living.'

This legitimacy deficit in the global South, together with the 'formal' rather than 'real' subsumption within capital of the semi-proletarian majority, carries with it the increased likelihood of challenge to the statecapital nexus by counter-hegemonic forces. Attempted reappropriations of the state and subversion of capitalism are implied, comprising re-assertions of national, and possibly post-national forms of sovereignty, including 'radical' food sovereignty, or 'substantive' food democracy (Tilzey, 2018). Such 'radical' counter-hegemonic forces potentially challenge, then, the essential foundations of capitalism, propounding a more Marxian (reversal of primitive accumulation) than Polanyian ('embedding' of capitalism) or 'formal' democratic, imaginary of social change (Tilzey, 2017). Thus, peripheral forms of capital accumulation, upon which the affluence and 'reified' discursive democracy of the North is premised, are generating more fundamental resistances to the state-capital nexus by 'radical' and counter-hegemonic food sovereignty movements in the global South. These are potentially most disruptive to the neoliberal food regime because it is in the global South, as a periphery for the Northern core, that the contradictions of capital accumulation are greatest and the legitimacy of the state is lowest. Consequently, it is in the South that the potential for transformations towards 'radical' or 'substantive' food democracy appears greatest. In the next section, we explore the dynamics 
of these counter-hegemonic resistances in relation to the Latin American states of Bolivia and Ecuador.

\section{The Prospects for Food Sovereignty as Counter-Hegemony: Experiences from Latin America and Lessons for 'Food Democracy'}

Counter-hegemony is here taken to mean opposition to, and autonomy from, the state-capital nexus-that is, from capitalism and its material and discursive supporting structures within the modern state, as 'modern sovereignty,' including that of 'formal' democracy. 'Radical' food sovereignty, as the ability to produce essential use values unmediated by the capitalist market, comprises a foundational element of such counterhegemony, as agrarian democracy. Crucial here, then also, is how we choose to define capitalism and its relation to the modern state because this definition will influence deeply how we envisage counter-hegemony as emancipatory politics. The essential point here is that participative democracy should be integral to, not independent from, the process of fundamental change away from capitalist social-property relations. In other words, 'political' emancipation will be less than meaningful unless undertaken in conjunction with 'economic' emancipation.

The definition of such counter-hegemony preferred here derives from the school of so-called 'political Marxism,' exemplified in the work of Brenner (1977, 1985), Wood (1995, 2009), and Mooers (1991), particularly. This approach has much in common with Gramscian and Poulantzian theory (see Poulantzas, 1978), with an emphasis on class dynamics and socialproperty relations within the state as key explanatory factors, whilst seeking to situate these dynamics within the wider enabling and constraining political economy of the world capitalist core-periphery structure (see Tilzey, 2018 , for full delineation of this approach). Following 'political Marxism' (see Tilzey, 2017, 2018; Vergara-Camus, 2014), we can understand capitalism as the contradictory combination of a set of social relations characterized by:

- The separation, wholly or partially, of workers from their means of production;

- Market dependence of producers (the compulsion to depend on a competitive market for the reproduction either of the worker [and family] or of the capitalist enterprise);

- The dominance of absolute private property (the extirpation of common rights in land, and the determination of the right to land only through the capitalist market and, therefore, the alienability of land through its commodification);

- The compulsive imperative of competition among producers (both workers and capitalists);

- The separation of the 'economic' from the 'political' in the form of the modern, capitalist state;
- Commodity fetishism and the compulsion to produce ever more commodities, with severe adverse implications for biophysical fabric of the planet;

- The predominance of exchange value over usevalue since surplus value extracted from workers is contained in commodities sold on the market.

The loss of the labourer's control over his/her labour power that is entailed in the expropriation of labourers from their means of production through the process of 'primitive accumulation' is, as we have seen, the absolutely key element in the emergence of the above characteristics. It is the obstruction or reversal of this process of primitive accumulation that comprises, as suggested, the absolutely key demand and desire of counterhegemonic peasant forces in the global South-this demand and desire persists because the majority of subalterns in the global South are semi-proletarians, still retaining some access to land, however inadequate this may be (they are formally, rather than really, subsumed within capitalist relations of production, the latter condition applying to proletarians). Such direct access to non-commodified land exemplifies a form of production in which the labourer (semi-proletarian) still controls his/her labour power and, to some extent, the degree and form of integration into the market. Thus, semi-proletarian peasants, even those who depend on the market for the fulfilment of a significant element of their subsistence needs, have more room for manoeuvre (more 'autonomy'), through the adjustment of production and consumption, than their fully proletarianized counterparts (Vergara-Camus, 2014). Under the prevailing conditions of precarity and 'jobless growth,' such autonomy, even if partial, is greatly valued. Unsurprisingly, the aspiration of many under such circumstances is to secure greater autonomy from the capitalist market, in other words, to secure greater access to land in order to achieve self-sufficiency in the production of basic use values such as food. The aspiration, in other words, is to secure a relation to the market that is one of opportunity, not of compulsion. Such a condition might be described variously as one of radical food sovereignty, agrarian democracy, or what we have elsewhere termed livelihood sovereignty (Tilzey, 2018).

The desire for agrarian democracy has indeed become ever more insistent as the contradictions of neoliberalism have mounted and the proletariat has increasingly acquired the status of a precariat. Access to land, however limited, often provides, under these conditions, the only real element of livelihood security. Thus, struggles in the countryside and in the city often have an essentially peasant character due to the incapacity of 'disarticulated' development (de Janvry, 1981) to provide salaried employment (real subsumption) as a viable alternative to secure the means of livelihood. Both peasants and workers seek refuge in the peasant situation, therefore, that is, in the auto-production of use values, to the greatest degree possible, to meet funda- 
mental needs. The rise of indigenous and ecological consciousness since the 1990s, and the simultaneous delegitimation of capitalist modernism, have served only to reinforce the hunger for land and aversion to full proletarianization (Moyo \& Yeros, 2005). Thus, the resolution of the unresolved agrarian question of the peasantry in much of the global South, particularly in the current ecologically constrained and increasingly volatile conjuncture, seems more than ever to be, of necessity, agrarian and peasant in nature. In this, the potential for mass mobilization on the part of the middle/lower peasantries, the precariat, and indigenous groups, for an agrarian solution to the contradictions, 'political' and 'ecological,' of capitalism (expressed in ongoing primitive accumulation) does not seem unrealistic. Indeed, the history of 'peasant wars' (Wolf, 1999), including the recent wave of anti-neoliberal uprisings in Bolivia, Ecuador, Nepal and elsewhere, indicate ample precedent for this (Moyo \& Yeros, 2005).

The point to be emphasized here is that, because of the operation of the 'imperial mode of living,' radical change is most likely to occur in the 'peripheries' of the capitalist world system. No inevitability or teleology is implied here, of course, and this assertion is most definitely not a manifesto for 'sitting back and waiting' for radical change to emerge from the global South. It is simply to identify where the potential agents of radical change are differentially located, and the great difficulty in getting radical messages to resonate with the majority in the imperium, where this majority's livelihood and imaginary are so deeply embroiled in a normalized 'imperial mode of living,' including that of liberal democracy. Indeed, the capacity of the state-capital nexus to subvert counter-hegemony, both through consumerism and 'formal' democracy, is amply demonstrated even in the global South, where we may point to the experiences of radical food sovereignty movements over the 'progressive' cycle of the Latin American 'pink tide' states.

Thus, the 1990s and 2000s saw widespread resistance in Latin America to the socially polarizing consequences of neoliberalism and to the progressive loss of national sovereignty (including sovereignty over food) that accompanied neo-imperial dependent 'development' (Veltmeyer \& Petras, 2000). Bolivia and Ecuador are exemplary 'pink tide' states where 'radical' forces, comprising middle/lower peasantry, semi-proletarians, proletarians and landless, and indigenous people, engaged in what proved to be a fateful alliance with 'progressive' national bourgeoisie and upper peasantry to displace neoliberalism, only to install national-popular regimes of reformist capitalism (note that our class analytical frame does not homogenize the peasantry, as does the 'populist' framework of McMichael, 2013, and others). Both states have a new commitment to greater state guidance and interventionism in the economy, to national food sovereignty (albeit largely rhetorical), formal democracy, and to the introduction of social programmes to alleviate the severe income disparities of the neoliberal era. Funds for the latter, however, are predicated on the proceeds of the 'new' extractivism of minerals, fossil-fuels, and agri-fuels, offered by the emergence of sub-imperial states, notably China (Veltmeyer \& Petras, 2014). These funds have been deployed to subsidize welfarism and infrastructure projects, placating counter-hegemonic constituencies, whose demands for radical land redistribution and land rights remain largely unmet. These 'national-popular' regimes have expanded and deepened liberal democracy, at least temporarily, but have failed meaningfully to challenge capitalist socialproperty relations (Tilzey, 2019a).

Thus, in Bolivia, a broad coalition of peasant, indigenous, and worker organizations (Pacto de Unidad) succeeded in overthrowing the neoliberal regime in 2003 and installing Evo Morales' MAS (Movimiento al Socialismo) party in power from 2005. Inter alia, these organizations sought an 'agrarian revolution,' entailing massive redistribution of land away from the oligarchy and in favour of the peasantry. The success of MAS was also dependent, however, on the support of the national bourgeoisie and the upper peasantry, and it was these constituencies which came to define MAS policies as national-popular capitalism, rather than an (agro)ecologically-based socialism. MAS came to be a regime which pursued a sub-hegemonic, or populist, programme of capitalist reformism, placating its counter-hegemonic constituency through welfarism, anti-imperial rhetoric, and the conferral of enhanced 'formal' democratic rights, and soothing the landed oligarchy through accelerated agri-food extractivism and effective exemption from agrarian reform (McKay, 2017; Tilzey, 2019a; Webber, 2017; see Catacora-Vargas et al., 2017, for status of agroecology in Bolivia).

The experience of Ecuador is very similar. The period leading up to 2006 saw counter-hegemonic social movements presenting a powerful challenge to neoliberalism. These movements, comprising the Mesa Agraria, signed an agreement with the future president Rafael Correa (a middle-class populist), in which he gave a commitment to initiate, upon election, an 'agrarian revolution' based on the peasant/indigenous movement demand for 'radical' food sovereignty. This was to be centred on the democratization of land access, and on state resources for the revival and stimulation of the 'peasant' economy (Clark, 2017; Giunta, 2014). Again, like Morales in Bolivia, however, it was never Correa's intention to challenge capitalist social-property relations. As in Bolivia, this was to be a national-popular, capitalist-reformist regime. Its populism pivoted on the nationally-focused bourgeoisies' and petty bourgeois class fractions' easy co-optation of the 'progressive' tendency within the food sovereignty movement, and the neutralization of the 'radical' tendency through social welfare payments, construction projects funded by extractivism, and a preoccupation with formal democratic process. The regime also placated the landed oligarchy by effectively exempting it from the 'agrarian revolution,' a revolution which, how- 
ever, has largely failed to materialize (Henderson, 2017; Intriago et al., 2017; Tilzey, 2019a).

These states, in their ability to subvert counterhegemony through consumerism, welfarism, and formal democracy, thus represent, in microcosm (albeit as a pale reflection of), the 'imperial mode of living.' Nonetheless, this ability to subvert and co-opt is timelimited, being dependent on the non-renewable character of neo-extractivism and the ecological despoliation that this entails. With counter-hegemonic demands for an 'agrarian revolution' unmet, the exhaustion of resources and soils through extractivism will presage dwindling funds for the 'compensatory' capitalist state, the unravelling of fragile populist alliances, and a resurgence of 'radical' resistance. This time around, the scarcity of 'ecological surplus' from extractivism will severely curtail the ability of the state-capital nexus to deflect counterhegemonic forces from seeking an agroecological and peasant-based resolution of the agrarian question-a reversal of 'primitive accumulation' to address both rural and urban precarity through 'livelihood sovereignty' (Tilzey, 2018, 2019a).

The experiences of the MST (Movimiento de Trabajadores Rurales sin Tierra) in Bolivia are exemplary in this regard and may constitute a model which has the potential to be 'scaled-up' in the event of (and, of course, to contribute to), the demise of the state-capital nexus. The dynamics of this movement help us to identify a strategy of emancipatory rural politics whereby counterhegemony, as food and livelihood sovereignty (agrarian democracy), may be implanted at 'local' level as a form of 'autonomy' (confronting 'capitalism from below'), whilst, simultaneously, recognizing the need to engage the state ('capitalism from above') to secure a more generalized form of autonomy. The MST seems to embody a 'dual strategy' approach, exploiting current opportunities for autonomy where possible, whilst amplifying the struggle for deeper and wider transformation through appropriation and subversion of the state-capital nexus itself. It also seems to represent the kind of 'radical' food sovereignty, or agrarian democracy, which we have identified in this article as counter-hegemony. Thus, the MST has embraced radical, participatory democracy, advocating collective ownership of land, and drawing on, while 'reinventing,' communal traditions inspired by the preColumbian ayllu (Fabricant, 2012). This, in short, entails a decommodification of livelihoods, most importantly by subverting, materially as well as ideologically, capitalist social-property relations. The reversal of primitive accumulation, through access to land, represents the preeminent prerequisite of this. This, in effect, is to invoke a Marxian, rather than a Polanyian, response to capitalist social-property relations through decommodification (see Vail, 2010, for more general discussion).

The MST has built an organizational structure that is democratic and participatory, capable of creating order and holding leaders and rank-and-file to account through collective governance (Fabricant, 2012). This is a form of grassroots citizenship, inspired by, but also reconfiguring, Andean principles of autonomy, self-governance, and participatory democracy. This stands in contrast to liberal citizenship as individualism, 'given' to members as a right by the state. The Andean ideal of the ayllu, imagined as community-held land and collective forms of governance and control, has become the principal framework for governing MST settlements. These modern ayllus are characterized by nucleated settlements, communal landholdings, rotational political and administrative offices, land redistribution, and rural tax collection. The MST has adapted the ayllu model to structure their political organization at the community, regional, and national levels. The state has fractionalized land and territory through a model of citizenship that has assigned absolute property rights to individuals, thus dichotomizing the 'political' and the 'economic' (Hylton \& Thomson, 2007). The MST asserts, by contrast, that complete dominion over land by an individual or group is itself illegitimate. Rather, land is a collective right and should entail stewardship rather than absolute dominion. The occupation of land signifies reclaiming and re-territorializing indigenous/peasant control and autonomy over land and other critical resources (Fabricant, 2012). The dynamic relationship between territorial autonomy and the ability to provide a political infrastructure that sustains humanity is designated by indigenous conceptualizations such as buen vivir, a reintegration of the 'political,' the 'economic,' and the 'ecological' (Tilzey, 2017). The MST's idea of food sovereignty and agroecology is deeply embedded in collaborative and collective forms of production. The MST has revived and politicized essentialized notions of Andean rural culture by establishing ayni (reciprocity) and minka (exchange) as forms of resistance to the capitalist, large-scale, agro-industrial production of the oligarchy (Fabricant, 2012). In their re-appropriation of this cultural model as antithetical to capitalism, the MST affirms the social, collective, and reciprocal forms of production, in which all members of the community benefit from family farming.

The MST has, however, been successful in establishing such settlements only in a small number of cases by exploiting a legal loophole which enables squatters to file a petition for ownership where the land in question is not being put to socially productive use (Fabricant, 2012). The MST is painfully aware, however, that such autonomy as exists in these small number of successful cases is founded on a fragile legal loophole within a more generalized system of absolute property rights which the capitalist state is committed to uphold (Tilzey, 2019a). It recognizes, therefore, that a far greater, and more thoroughgoing, transformation of social-property relations is required if its model of ayllu-inspired autonomy for the landless and land-poor peasantry is to be more widely implanted. This serves perhaps to highlight the limitations of autonomism (and 'formal' food democracy) as a doctrine that assumes that real change can occur 'without taking power' or, in other words, with- 
out addressing the causal basis of poverty, marginalization and ecological despoliation generated by 'capitalism from above,' orchestrated by the state. This is recognized by the MST. While seizing all the opportunities available at the local level to secure access to land and institute collective ways of life as food sovereignty, the MST recognizes that the limits to this strategy are defined precisely by the forces of unsustainability that need to be confronted. This confrontation can occur only if the struggle is taken to the state by means of a dual strategy designed fundamentally to transform capitalist social-property relations.

\section{Conclusion}

The experiences of Bolivia and Ecuador serve to demonstrate just how challenging it is for counter-hegemonic social movements to displace the state-capital nexus, even where these movements comprise the majority of the citizenry, possess clearly defined and feasible objectives for 'radical' food sovereignty, and are offered relatively insecure and inadequate welfare/employment benefits in 'compensation' for the thwarted 'agrarian revolution.' How much greater, then, are the challenges for counter-hegemony in the global North, where such movements are much more marginal, comprise a small minority of the citizenry, face severe structural obstacles to 'radical' alternatives (that consequently appear utopian), and where the aspiration and tangible reality for the majority, at least in the shorter-term, is one of relatively secure employment and consumerism within the 'imperial mode of living.' This is not to trivialize the important efforts of 'food democracy' movements in the global North, such as those involved in food cooperatives and community-supported agriculture, but merely to point up how much more work and effort are required: First, to 'visibilize' and 'de-reify' the 'imperial mode of living'; second, to avoid co-optation into the material rewards of consumerism and the ideological obfuscations of nationalism (for example, Brexit and Trumpism); and, third and perhaps most important, to address the immense structural constraints presented by deeply entrenched private property rights, the separation of the citizen majority from the means of livelihood, and the commodification of those means of livelihood (notably land) such that they are unavailable other than to a wealthy few. Part of this work is to politicize, rather than to construe as 'evolutionary' inevitability, the phenomenon of primitive accumulation (that is, the historical and forced separation of the majority from their means of livelihood), and to lay bare the 'predication' of the imperial mode of living, and the preoccupation with formal rights and democracy, upon the perpetuation of this phenomenon throughout much of the global South today. This is simultaneously to reformulate the problem of 'food democracy' as an issue, not merely of deepening and extending democracy around principle of 'right to food,' but also of challenging the capitalist social-property relations which underlie social inequality and ecological unsustainability. This, ultimately, is a question of redressing primitive accumulation, through 'radical' food sovereignty as agrarian democracy.

\section{Acknowledgments}

The author would like to acknowledge the very helpful comments of two anonymous referees and the editors on an earlier draft of this article. He would also like to thank the editors for inviting him to contribute to this thematic issue. Finally, he would like to acknowledge the financial support of CAWR, Coventry University in the publication of this article.

\section{Conflict of Interests}

The author declares no conflict of interests.

\section{References}

Altieri, M. A., \& Toledo, V. M. (2011). The agroecological revolution in Latin America: Rescuing nature, ensuring food sovereignty and empowering peasants. The Journal of Peasant Studies, 38, 587-612.

Bernstein, H. (2010). The class dynamics of agrarian change. Halifax: Fernwood.

Bieler, A., \& Morton, A. (2004). A critical theory route to hegemony, world order and historical change: NeoGramscian perspectives in International Relations. Capital and Class, 82(Spring), 85-113.

Bornemann, B., \& Weiland, S. (2019). Empowering people: Democratising the food system? Exploring the democratic potential of food-related empowerment forms. Politics and Governance, 7(4), 105-118.

Boyer, R., \& Saillard, Y. (Eds.). (2002). Regulation theory: The state of the art. London: Routledge.

Brand, U., \& Wissen, M. (2018). The limits to capitalist nature: Theorizing and overcoming the imperial mode of living. London: Rowman and Littlefield.

Brenner, R. (1977). The origins of capitalist development: A critique of Neo-Smithian Marxism. New Left Review, 104, 25-93.

Brenner, R. (1985). The agrarian roots of European capitalism. In T. Aston \& C. Philpin (Eds.), The Brenner debate: Agrarian class structure and economic development in pre-industrial Europe (pp. 213-328). Cambridge: Cambridge University Press.

Caffentzis, G. (2010). The future of 'The Commons': Neoliberalism's 'plan B' or the original disaccumulation of capital? New Formations, 69, 23-41.

Catacora-Vargas, G., Piepenstock, A., Sotomayor, C., Cuentas, D., Cruz, A., \& Delgado, F. (2017). Brief historical review of agroecology in Bolivia. Agroecology and Sustainable Food Systems, 41(3/4), 429-447.

Clark, P. (2017). Neo-developmentalism and a "vía campesina" for rural development: Unreconciled projects in Ecuador's citizen's revolution. Journal of 
Agrarian Change, 17(2), 348-364.

Cox, R. (1993). Gramsci, hegemony, and international relations: An essay in method. In S. Gill (Ed.), Gramsci, historical materialism, and international relations (pp. 49-66). Cambridge: Cambridge University Press.

de Janvry, A. (1981). The agrarian question and reformism in Latin America. Baltimore, MD: Johns Hopkins University Press.

Dryzek, J. (2000). Deliberative democracy and beyond: Liberals, critics, contestations. London: Oxford University Press.

Fabricant, N. (2012). Mobilizing Bolivia's displaced: Indigenous politics and the struggle over land. Chapel Hill, NC: University of North Carolina Press.

Federici, S., \& Caffentzis, G. (2014). Commons against and beyond capitalism. Community Development Journal, 49, 92-105.

Giunta, I. (2014). Food sovereignty in Ecuador: Peasant struggles and the challenges of institutionalization. The Journal of Peasant Studies, 41(6), 1201-1224.

Gramsci, A. (1971). Selections from the prison notebooks. New York, NY: International Publishers.

Habermas, J. (1996). Between facts and norms: Contributions to a discourse theory of law and democracy. Cambridge, MA: MIT Press.

Hardt, M., \& Negri, A. (2000). Empire. Cambridge, MA: Harvard University Press.

Hassanein, N. (2008). Locating food democracy: Theoretical and practical ingredients. Journal of Hunger and Environmental Nutrition, 3(2/3), 286-308.

Henderson, T. (2017). State-peasant movement relations and the politics of food sovereignty in Mexico and Ecuador. The Journal of Peasant Studies, 44(1), 33-55.

Holt-Gimenez, E., \& Shattuck, A. (2011). Food crises, food regimes and food movements: Rumblings of reform or tides of transformation? The Journal of Peasant Studies, 38, 109-144.

Holt-Gimenez, E., \& van Lammeren, I. (2019). Can food as a commons advance food sovereignty? In J. L. Vivero-Pol, T. Ferrando, O. de Schutter, \& U. Mattei (Eds.), Routledge handbook of food as a commons (pp. 313-328). London: Routledge.

Hylton. F., \& Thomson, S. (2007). Revolutionary horizons: Past and present in Bolivian politics. London: Verso.

Intriago, R., Gortaire Amézcua, R., Bravo, E., \& O'Connell, C. (2017). Agroecology in Ecuador: Historical processes, achievements, and challenges. Agroecology and Sustainable Food Systems, 41(3/4), 311-328.

Jansen, K. (2015). The debate on food sovereignty theory: Agrarian capitalism, dispossession and agroecology. The Journal of Peasant Studies, 42(1), 213-232.

Jessop, B. (2005). Critical realism and the strategicrelational approach. New Formations, 56, 40-53.

Jessop, B., \& Sum, N. L. (2013). Towards a cultural political economy: Putting culture in its place in political economy. Cheltenham: Edward Elgar.

Marini, R. M. (1972). Brazilian subimperialism. Monthly
Review, 23(9), 14-24.

Marini, R. M. (1973). Dialéctica de la dependência [Dialectic of dependence]. Mexico City: Editorial Era.

Marx, K. (1981). Capital. London: Penguin.

McKay, B. (2017). Agrarian extractivism in Bolivia. World Development, 97(September), 199-211.

McMichael, P. (2013). Food regimes and agrarian questions. Halifax and Winnipeg: Fernwood.

Mooers, C. (1991). The making of bourgeois Europe: Absolutism, revolution, and the rise of capitalism in England, France, and Germany. London: Verso.

Mooers, C. (2014). Imperial subjects: Citizenship in an age of crisis and empire. London: Bloomsbury.

Moyo, S., \& Yeros, P. (Eds.). (2005). Reclaiming the land: The resurgence of rural movements in Africa, Asia, and Latin America. London: Zed Press.

Patel, R. (2011). What does food sovereignty look like? In H. Wittman, A. A. Desmarais, \& N. Wiebe (Eds.), Food sovereignty: Reconnecting food, nature, and community (pp. 186-195). Oxford: Pambazuka Press.

Perelman, M. (2000). The invention of capitalism: Classical political economy and the secret history of primitive accumulation. Durham: Duke University Press.

Polanyi, K. (1957). The great transformation: The political and economic origins of our time. Boston, MA: Beacon Press.

Potter, C., \& Tilzey, M. (2005). Agricultural policy discourses in the European post-Fordist transition: Neoliberalism, neomercantilism and multifunctionality. Progress in Human Geography, 29(5), 581-600.

Poulantzas, N. (1978). State, power, socialism. London: Verso.

Ribot, J., \& Peluso, N. (2003). A theory of access. Rural Sociology, 68(2), 153-181.

Taylor, P. (1994). The state as container: Territoriality in the modern world-system. Progress in Human Geography, 18, 151-162.

Thompson, E. P. (1991). The making of the English working class. London: Penguin Books.

Tilzey, M. (2017). Reintegrating economy, society, and environment for cooperative futures: Polanyi, Marx, and food sovereignty. Journal of Rural Studies, 53(July), 317-334.

Tilzey, M. (2018). Political ecology, food regimes, and food sovereignty: Crisis, resistance, and resilience. London: Palgrave Macmillan.

Tilzey, M. (2019a). Authoritarian populism and neoextractivism in Bolivia and Ecuador: The unresolved agrarian question and the prospects for food sovereignty as counter-hegemony. The Journal of Peasant Studies, 46(3), 626-652.

Tilzey, M. (2019b). Food regimes, state, capital, and class: Friedmann and McMichael revisited. Sociologia Ruralis, 59(2), 230-254.

Vail, J. (2010). Decommodification and egalitarian political economy. Politics \& Society, 38(3), 310-346.

van Apeldoorn, B., de Graaff, N., \& Overbeek, H. (2012). The reconfiguration of the global state-capital nexus. 
Globalizations, 9, 471-486.

van der Ploeg, J. D. (2008). The new peasantries: Struggles for autonomy and sustainability in an era of empire and globalization. London: Earthscan.

Veltmeyer, H., \& Petras, J. (2000). The dynamics of social change in Latin America. London: Palgrave Macmillan.

Veltmeyer, H., \& Petras, J. (2014). The new extractivism: A post-neoliberal development model or imperialism of the twenty-first century? London: Zed Press.

Vergara-Camus, L. (2014). Land and freedom: The MST, the Zapatistas, and peasant alternatives to neoliberalism. London: Zed Books.

Vivero-Pol, J. L. (2017). The idea of food as commons or commodity in academia: A systematic review of English scholarly texts. Journal of Rural Studies, 53(July), 182-201.

Vivero-Pol, J. L. (2019). The idea of food as a commons: Multiple understandings for multiple dimensions of food. In J. L. Vivero-Pol, T. Ferrando, O. de Schutter, \& U. Mattei (Eds.), Routledge handbook of food as a commons (pp. 25-41). London: Routledge.

Vivero-Pol, J. L., Ferrando, T., de Schutter, O., \& Mattei,
U. (Eds.). (2019). Routledge handbook of food as a commons. London: Routledge.

Webber, J. (2017). Evo Morales, transformismo, and the consolidation of agrarian capitalism in Bolivia. Journal of Agrarian Change, 17(2), 330-347.

Wolf, E. R. (1982). Europe and the people without history. Berkeley, CA: University of California Press.

Wolf, E. R. (1999). Peasant wars of the Twentieth Century. Norman, OK: University of Oklahoma Press.

Wood, E. M. (1991). The pristine culture of capitalism: An essay on old regimes and modern states. London: Verso.

Wood, E. M. (1995). Democracy against capitalism: Renewing historical materialism. Cambridge: Cambridge University Press.

Wood, E. M. (2005). Empire of capital. London: Verso.

Wood, E. M. (2009). Peasants and the market imperative: The origins of capitalism. In A. H. Akram-Lodhi \& C. Kay (Eds.), Peasants and globalization: Political economy, rural transformation, and the agrarian question (pp. 37-56). Abingdon: Routledge.

\section{About the Author}

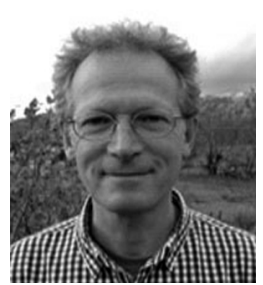

Mark Tilzey (PhD) is Associate Professor in the Governance of Food Systems for Resilience, Centre for Agroecology, Water and Resilience, Coventry University, UK. His research interests lie in political ecology, food regimes, agrarian change and agroecology, agri-environmental politics and governance, and the international political economy of agri-food systems. He is the author of Political Ecology, Food Regimes, and Food Sovereignty: Crisis, Resistance, Resilience (Palgrave Macmillan, 2018). 